\title{
Portable Network Graphics
}

National Cancer Institute

\section{Source}

National Cancer Institute. Portable Network Graphics. NCI Thesaurus. Code C85437.

An extensible file format for lossless data compression of images. 